\title{
Pengembangan Kemampuan Menulis pada Anak Usia 4-5 Tahun di TK Primagama
}

\author{
Adinda Rohadati Aisy, Hafidzah Nur Adzani \\ Pendidikan Guru Pendidikan Anak Usia Dini, Fakultas Keguruan dan Ilmu Pendidikan, Universitas Sebelas \\ Maret \\ Jl. Ir. Sutami No.36 A, Pucangsawit, Kec. Jebres, Kota Surakarta, Jawa Tengah 57126, Indonesia \\ E-mail: fidzahadzani@gmail.com
}

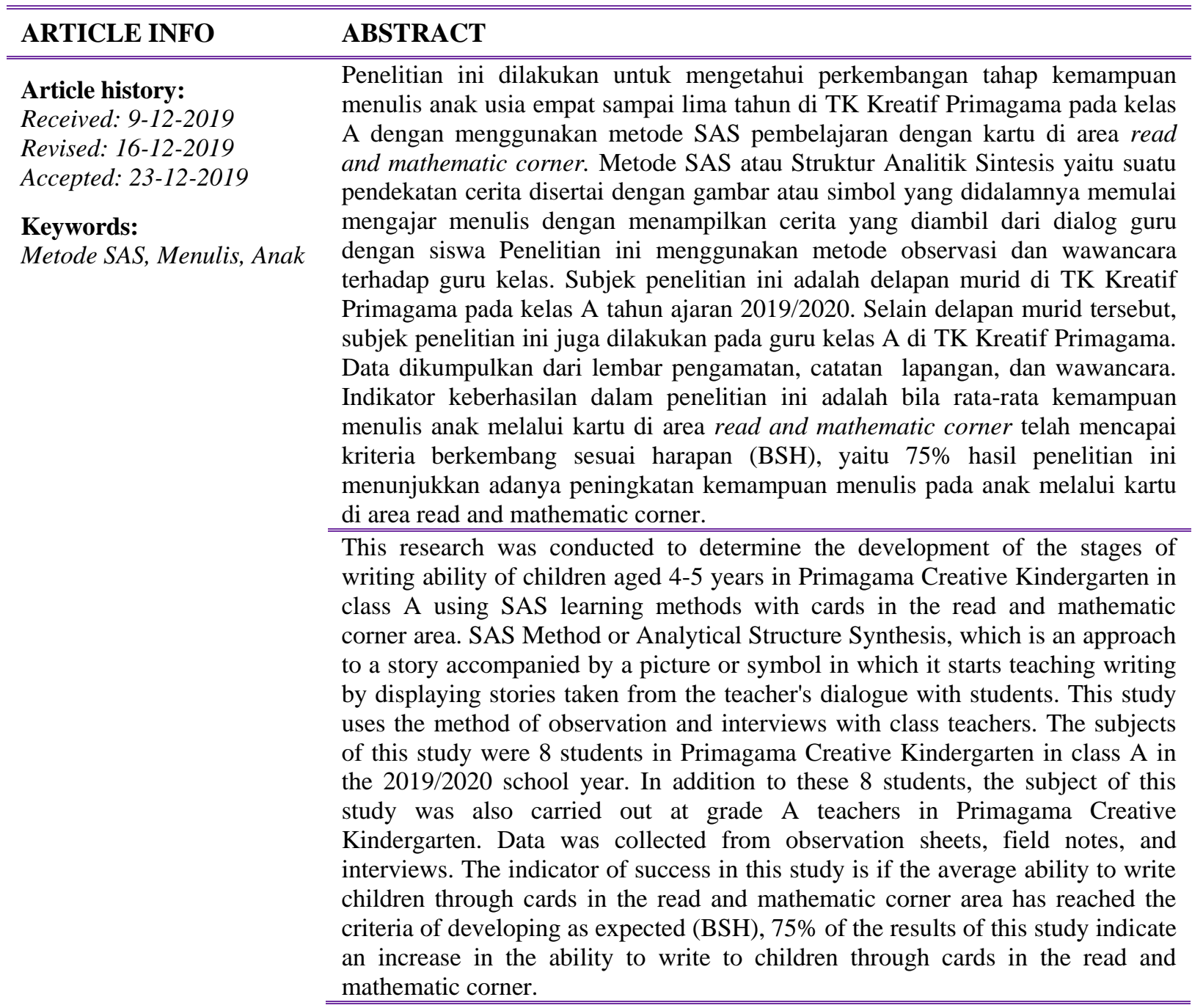

\section{PENDAHULUAN}

Anak usia dini menurut National Association For The Education Of Young Children (NAEYC) dalam (Dadan Suryana, n.d.), adalah anak yang dalam rentang usia baru lahir sampai dengan usia 8 tahun. Anak usia dini adalah anak yang berada pada rentan usia 0-6 tahun Undangundang Sisdiknas tahun 2003 dalam (Kesowo, 2003), dan menurut para pakar Pendidikan Anak Usia Dini (PAUD) berada pada rentan usia 0-8 tahun. Menurut Mansur (2005: 88) dalam (Tatik Ariyanti, 2016), Anak usia dini adalah kelompok anak yang berada dalam proses pertumbuhan dan perkembangan yang bersifat unik. Pendidikan anak usia dini adalah suatu upaya pembinaan yang ditujukan kepada anak sejak lahir sampai usia 6 tahun yang dilakukan melalui pembinaan rangsangan 
pendidikan untuk membantu pertumbuhan dan perkembangan jasmani dan rohani agar anak memiliki kesiapan dalam memasuki pendidikan selanjutnya atau setara dengan pendidikan Sekolah Dasar (SD).

Pendidikan anak usia dini diharapkan dapat membantu mengembangan kemampuan berbagai potensi dalam diri anak yang berguna sebagai keterampilan hidup anak selanjutnya dan melanjutkan ke jenjang berikutnya tanpa adanya hambatan. Aspek pengembangan yang di stimulasi meliputi nilai agama moral, sosial, emosional, kognitif, bahasa, seni, fisik motorik. Dalam setiap kegiatan pembelajaran anak usia dini menerapkan metode bermain seraya belajar dan belajar melalui bermain sebagai slogan dalam pembelajarannya. Salah satu aspek yang dikembangan pada anak usia dini adalah bahasa, yang meliputi bahasa reseptif. Bahasa reseptif adalah kemampuan berbahasa anak untuk menangkap, memahami, dan menyampaikan informasi yang didapatkan melalui bahasa lisan. Materi pengembangan bahasa reseptif mencakup kegiatan membaca dan menyimak anak. Selain bahasa reseptif, aspek yang dikembangkan pada anak usia dini juga meliputi bahasa ekspresif. Menurut (Asiah, 2018) Suhartono (2005:20) bahasa ekspresif adalah kemampuan berbahasa anak dengan mengucapkan bunyi-bunyi artikulasi atau kata-kata untuk mengekspresikan, menyatakan serta menyampaikan pikiran, gagasan, dan perasaan. Materi pengembangan bahasa ekspresif mencakup kegiatan berbicara anak. Aspek perkembangan bahasa anak usia dini selanjutnya adalah keaksaraan. Menurut Peraturan Menteri Pendidikan dan Kebudayaan Republik Indonesia Nomer 137 Tahun 2014 tentang Standar Nasional Pendidikan Anak Usia Dini, pasal 10 berbunyi "Keaksaraan mencakup pemahaman terhadap hubungan bentuk dan bunyi huruf, meniru bentuk huruf, serta memahami kata dan cerita"(NUH, 2014).

Belajar menulis untuk anak perlu diajarkan sejak dini. Meskipun keterampilan menulis bukan aspek utama dalam Pendidikan Anak Usia Dini (PAUD). Namun tuntutan anak untuk bisa dan mampu membaca dan menulis pada jenjang pendidikan selanjutnya. Hal ini yang menjadikan fokus guru agar dapat mengembangkan kemampuan menulis anak sesuai pada tahapan perkembangan. Adapun tahapan kemampuan menulis anak usia dini menurut $\mathrm{p}$ terdiri dari 5 bagian, yaitu:

1. Tahap mencoret usia 2,5-3 tahun, yaitu saat anak mulai belajar tentang bahasa tulisan dan bagaimana mengajarkan tulisan ini.

2. Tahap pengulangan secara linier usia 4 tahun, yaitu saat anak berpikir bahwa suatu kata merujuk pada sesuatu yang besar dan mempunyai tali yang panjang.

3. Tahap menulis secara acak usia 4-5 tahun, yaitu saat anak dapat mengubah tulisan menjadi kata yang mengandung pesan.

4. Tahap menulis tulisan nama usia 5,5 tahun, pada fase ini berbagai kata yang mengandung akhiran yang sama dihadirkan dengan kata dan tulisan.

5. Tahap menulis kalimat pendek usia diatas 5 tahun, yaitu kalimat yang ditulis anak berupa subjek dan predikat.

Tahap perkembangan menulis anak usia 4-5 tahun dapat berkembang apabila kegiatan menulis atas dasar keinginan sendiri maupun tanpa paksaan dari orang sekitarnya. Menurut Depdiknas (Anggalia \& Karmila, 2013) terdapat prinsip-prinsip yang perlu diperhatikan dalam menumbuhkan keinginan menulis anak.

1. Prinsip penggunaan tanda atau simbol

Guru memberi kesempatan yang banyak pada anak untuk melatih kelenturan motorik halus anak.

2. Prinsip pengulangan

Memberikan latihan pengulangan.

3. Prinsip keluwesan

Guru memperkenalkan tulisan pertama kali pada anak berupa simbol atau tanda yang dekat dan dikenal anak.

4. Prinsip pengungkapan

Memberikan kesempatan pada anak untuk mengungkapkan berbagai pengalamannya berkaitan dengan tulisan yang telah dibuatnya.

5. Prinsip mencontoh

Guru sering mengulang berbagai contoh tulisan atau kata dengan konteks yang sama.

6. Prinsip penguatan 
Guru memberikan penguatan berupa penghargaan atau pujian terhadap hasil tulisan anak.

Menurut Supriyadi (1996 : 334 -335) pengertian Metode Struktur Analitik Sintetik (SAS) adalah suatu pendekatan cerita disertai gambar yang didalamnya terkandung unsur analitik sintetik. Metode SAS menurut Djauzak (prastiwi, 2012) adalah suatu metode pembelajaran menulis permulaan yang didasarkan atas pendekatan cerita yakni cara memulai mengajar menulis dengan menampilkan cerita yang diambil dari dialog siswa dan guru atau siswa satu dengan siswa yang lain. Kegiatan pembelajaran menulis permulaan dengan metode Struktural Analitik Sintetik (SAS) dilakukan dengan langkah-langkah sebagai berikut :

1. Guru bercerita atau berdialog dengan siswa,

2. Memperlihatkan ambar yang berhubungan dengan isi cerita,

3. Menulis beberapa kalimat sebagai kesimpulan dari isi cerita,

4. Menulis satu kalimat yangd iambil dari isi cerita,

5. Menulis kata-kata sebagai uraian dari kalimat,

6. Menulis suku-suku kata sebagai uraian dari kata-kata,

7. Menuliskan huruf-huruf sebagai uraian dari suku-suku kata,

8. Mensintesiskan huruf-huruf menjadi suku-suku kata,

9. Menyatukan kata-kata menjadi kalimat.

Agar siswa memiliki kemampuan menulis, maka setiap langkah tersebut dapat dilakukan oleh siswa dengan cara menyalin tulisan yang ditulis guru dalam setiap langkah pembelajaran. Metode struktur analitik sintetik merupakan suatu pendekatan cerita disertai gambar yang didalamnya terkandung unsur analitik sintetik. (Supriyadi, 1996: 334- 335). Metode struktur analitik sintetik menggunakan beberapa langkah dengan menampilkan keseluruhan, melakukan proses penguraian dan melakukan penggalan pada struktur semula, sehingga akan mempermudah siswa untuk mengenal huruf, mencontoh huruf serta melafalkannya dalam pembelajaran mengenal membaca dan menulis permulaan. Pembelajaran dengan metode struktur analitik sintetik menggunakan berbagai macam permainan, seperti keterampilan menulis kartu huruf, kartu suku-suku kata dan kata, kartu kalimat.

Adanya metode struktur analitik sintetik (SAS) yang diterapkan oleh guru terhadap pembelajaran di kelas, penggunaan media juga berpengaruh terhadap keberhasilan pengembangan menulis anak usia 4-5 tahun. Penggunaan media berupa flash card atau kartu kata sendiri menurut Doman (dalam Musta'in, 2008:14) merupakan "kartu yang dibuat dari kertas putih yang ditempeli huruf-huruf berukuran besar dengan kertas emas berwarna merah, sehingga membentuk kata yang dekat dengan anak". Kartu ini juga bisa divariasikan dengan kartu lain. Modifikasi media yang telah diubah sesuai dengan kebutuhan dan tahap perkembangan usia anak.

Pengembangan kemampuan dan keterampilan anak usia dini berkaitan dengan Tri Pusat Pendidikan yang mempunyai peranan penting terhadap keberhasilan anak dalam melewati setiap fase perkembangan dalam hidupnya.

1. Lingkungan keluarga

Merupakan lingkungan pendidikan yang pertama dan utama. Salah satu tugas orang tua dalam mendidik adalah dengan membimbing mereka menuju kedewasaan baik jasmani maupun rohani. Keluarga adalah wadah untuk mengembangkan dan membentuk dari dalam sosialnya, dan membentuk sikap. Dasar tanggung jawab orang tua kepada anaknya adalah: 1) adanya dorongan cinta kasih; 2) pemberian morivasi moral; 3) tanggungjawab sosial; 4) memelihara dan membesarkan anaknya; 5 )memberikan berbagai ilmu pengetahuan dan keterampilan yangberguna untuk kehidupanya.

2. Lingkungan sekolah

Pendidikan sekolah adalah lanjutan dari pendidikan keluarga. Sekolah merupakan jembatan bagi anak untuk menghubungkan mereka dari lingkungan keluarga dengan lingkungan masyarakat. Sebagai lembaga formal, sekolah lahir dan berkembang secara efektif dan efisien. Sekolah berfungsi untuk mendidik dan mengajar.

3. Lingkungan masyarakat 
Lingkungan masyarakat berkenaan dengan perkembangan dan perubahan kelakuan anak. Masyarakat merupakan bentuk kehidupan sosial dengan tata nilai budaya. Masyarakat dijadikan wadah dalam pendidikan sosial, agama, suku, dan lainya.

Dalam konteks pendidikan, masyarakat merupakan lingkungan pendidikan ketiga setelah keluarga dan sekolah. Pendidikan ini dimulai saat anak-anak mulai lepas dari keluarga dan berada diluar dari pendidikan sekolah. Pendidikan masyarakat mampu membentuk kebiasaan, membentuk pengertian (pengetahuan), sikap, minat, dan kesusilaan. Elemen Tripusat pendidikan ini berkolaborasi untuk meningkatkan aspek-aspek perkembangan anak serta penanaman pengetahuan.

\section{METODE}

Metode penelitian yang digunakan adalah metode observasi kelas terhadap 8 subjek penelitian serta wawancara dengan guru kelas sebagai narasumber. Dalam pelaksanaan metode ini dengan cara pengamatan kelas dalam kegiatan pembelajaran guru dengan metode struktur analitik sintetik untuk mengembangkan kemampuan menulis anak. Penggunaan instrumen berupa lembar evaluasi penilaian yang disertai dengan rubrik penilaian perkembangan sesuai tahap perkembangan anak yang diambil dari STPPA 137 Tahun 2014 serta pedoman wawancara terhadap guru kelas mengenai metode yang digunakan guru dalam menstimulasi kemampuan menulis anak. Pengumpulan dokumen-dokumen lembar kegiatan anak yang digunakan pada saat itu dan beberapa dokumentasi pada saat guru kelas memberikan pembelajaran.

Pendekatan penelitian yang digunakan dalam penelitian ini adalah penelitian kualitatif dengan mengumpulkan data-data yang bersifat kualitatif dari subjek penelitian yang terdiri dari 8 murid kelas A dan 1 guru kelas di TK. Data kualitatif yang dimaksud adalah deskripsi kegiatan pengenalan simbol huruf, h-i-j dan angka 20-30.data berupa tabel perkembangan anak yang disertai dengan deskripsi Belum Berkembang(BB), Masih berkembang (MB), Berkembang sesuai Harapan(BSH), dan Berkembang Sangat Baik (BSB) serta adanya kriteria per deskripsi.

Adapun lokasi penelitian ini dilaksanakan di TK Kreatif Primagama, yang berada di Kota Surakarta. Penelitian ini dilaksanakan pada hari Senin tanggal 2 bulan Desember tahun 2019.

\section{HASIL DAN PEMBAHASAN}

\section{Hasil}

Dari hasil pengamatan atau observasi diketahui bahwa TK Kreatif Primagama Kelas A dalam pengembangan kemampuan menulis pada anak berkembang sesuai harapan. Dari subjek penelitian 6 dari 8 murid mampu menuliskan namanya masing-masing tanpa bantuan dan menulis urutan angka sebelum maupun setelah rentang angka 20-30 serta membuat coretan di lembar kegiatan anak dengan metode penyampaian materi oleh guru menggunakan metode SAS (Struktur Analitik Sintesis) yaitu suatu pendekatan cerita disertai dengan gambar atau simbol yang di dalamnya memulai mengajar menulis dengan menampilkan cerita yang diambil dari dialog guru dengan siswa menggunakan media flash card.

Adapun kegiatan pembelajaran TK Kreatif Primagama berfokus pada Akademik untuk menunjang pengetahuan anak ketika akan masuk ke jenjang pendidikan selanjutnya, sehingga dalam kegiatan pembelajaran lebih mengacu pada keterampilan membaca dan menulis anak dengan model pembelajaran kelompok, yaitu kegiatan anak dilakukan bersama-sama dengan guru. Media flash card yang digunakan beragam bentuk dan warna sehingga anak senang dan tertarik dalam kegiatan membaca dan menulis.

Pembelajaran dalam Pendidikan Anak Usia Dini (PAUD) memiliki 3 pusat lembaga pendidikan yang saling berkontribusi utnuk menyukseskan stimulasi dalam aspek perkembangan bahasa di lingkungan keluarga, lingkungan sekolah, dan lingkungan masyarakat. Keberhasilan dalam pengembangan keterampilan menulis anak tidak terlepas dari peran orang tua yang aktif untuk mengulang kegiatan belajar anak disekolah yang dapat dilihat dari Daily Record. Daily Record adalah buku Perkembangan anak di mana setiap harinya guru memberikan deskripsi kegiatan sehari anak saat berada di sekolah, sehingga orang tua mampu mengetahui perkembangan anak setiap harinya.

Adapun data penelitian berupa lembar evaluasi penilaian dan rubrik perkembangan anak, 
berikut data dari hasil penelitian di TK Kreatif Primagama kelas A usia 4-5 tahun.

Tabel 1. Lembar Penilaian

\begin{tabular}{|c|c|c|c|c|c|c|c|c|c|c|c|c|c|}
\hline \multirow{3}{*}{ No. } & \multirow{3}{*}{ Nama } & \multicolumn{12}{|c|}{ Indikator } \\
\hline & & \multicolumn{4}{|c|}{ Mengenal Simbol } & \multicolumn{4}{|c|}{ Membuat Coretan Bermakna } & \multicolumn{4}{|c|}{ Meniru Huruf H-I-J } \\
\hline & & BB & MB & BSH & BSB & BB & MB & BSH & BSB & BB & MB & BSH & BSB \\
\hline 1. & DSJY & & $\sqrt{ }$ & & & & $\sqrt{ }$ & & & $\sqrt{ }$ & & & \\
\hline 2. & GDG & & & $\sqrt{ }$ & & & & $\sqrt{ }$ & & & & $\sqrt{ }$ & \\
\hline 3. & AGG & & & $\sqrt{ }$ & & & $\sqrt{ }$ & & & $\sqrt{ }$ & & & \\
\hline 4. & IPA & & & $\sqrt{ }$ & & & & $\sqrt{ }$ & & & & $\sqrt{ }$ & \\
\hline 5 . & KR & $\sqrt{ }$ & & & & & $\sqrt{ }$ & & & & $\sqrt{ }$ & & \\
\hline 6. & MPB & & & & $\sqrt{ }$ & & & $\sqrt{ }$ & & & & & $\sqrt{ }$ \\
\hline 7. & RDR & & & $\sqrt{ }$ & & & & $\sqrt{ }$ & & & & $\sqrt{ }$ & \\
\hline 8. & ZA & & & $\sqrt{ }$ & & & & $\sqrt{ }$ & & & & $\sqrt{ }$ & \\
\hline
\end{tabular}

Tabel 2. Rubrik Perkembangan

\begin{tabular}{|c|c|c|c|c|c|}
\hline No. & Rubrik & BB & MB & BSH & BSB \\
\hline 1. & Mengenal Simbol & $\begin{array}{l}\text { Anak belum mampu } \\
\text { menghubungkan } \\
\text { benda-benda } \\
\text { konkret dengan } \\
\text { lambang bilangan } \\
20-30\end{array}$ & $\begin{array}{l}\text { Anak masih } \\
\text { memerlukan } \\
\text { bantuan dalam } \\
\text { menghubungkan } \\
\text { benda-benda } \\
\text { konkret dengan } \\
\text { lambang bilangan } \\
20-30\end{array}$ & $\begin{array}{l}\text { Anak sudah mampu } \\
\text { secara mandiri } \\
\text { dalam } \\
\text { menghubungkan } \\
\text { benda-benda } \\
\text { konkret dengan } \\
\text { lambang bilangan } \\
20-30\end{array}$ & $\begin{array}{l}\text { Anak mampu secara } \\
\text { mandiri dan dapat } \\
\text { membantu } \\
\text { temannya dalam } \\
\text { menghubungkan } \\
\text { benda-benda } \\
\text { konkret dengan } \\
\text { lambang bilangan } \\
20-30\end{array}$ \\
\hline 2. & $\begin{array}{l}\text { Membuat Coretan yang } \\
\text { Bermakna }\end{array}$ & $\begin{array}{l}\text { Anak belum mampu } \\
\text { menceritakan apa } \\
\text { yang ditulis } \\
\text { walaupun tidak } \\
\text { sama tulisan dengan } \\
\text { bahasa yang } \\
\text { diungkapkan }\end{array}$ & $\begin{array}{l}\text { Anak masih } \\
\text { memerlukan } \\
\text { bantuan dalam } \\
\text { menceritakan apa } \\
\text { yang ditulis } \\
\text { walaupun tidak } \\
\text { sama tulisan dengan } \\
\text { bahasa yang } \\
\text { diungkapkan }\end{array}$ & $\begin{array}{l}\text { Anak sudah mampu } \\
\text { secara mandiri } \\
\text { menceritakan apa } \\
\text { yang ditulis } \\
\text { walaupun tidak } \\
\text { sama tulisan dengan } \\
\text { bahasa yang } \\
\text { diungkapkan }\end{array}$ & $\begin{array}{l}\text { Anak mampu secara } \\
\text { mandiri dan dapat } \\
\text { membantu } \\
\text { temannya dalam } \\
\text { menceritakan apa } \\
\text { yang ditulis } \\
\text { walaupun tidak } \\
\text { sama tulisan dengan } \\
\text { bahasa yang } \\
\text { diungkapkan }\end{array}$ \\
\hline 3. & $\begin{array}{l}\text { Meniru (menuliskan dan } \\
\text { mengucapkan) Huruf H-I-J }\end{array}$ & $\begin{array}{l}\text { Anak belum mampu } \\
\text { menuliskan huruf- } \\
\text { huruf yang } \\
\text { dicontohkan dengan } \\
\text { cara meniru }\end{array}$ & $\begin{array}{l}\text { Anak masih } \\
\text { memerlukan } \\
\text { bantuan dalam } \\
\text { menuliskan huruf- } \\
\text { huruf yang } \\
\text { dicontohkan dengan } \\
\text { cara meniru }\end{array}$ & $\begin{array}{l}\text { Anak sudah mampu } \\
\text { secara mandiri } \\
\text { menuliskan huruf- } \\
\text { huruf yang } \\
\text { dicontohkan dengan } \\
\text { cara meniru }\end{array}$ & $\begin{array}{l}\text { Anak mampu secara } \\
\text { mandiri dan dapat } \\
\text { membantu } \\
\text { temannya dalam } \\
\text { menuliskan huruf- } \\
\text { huruf yang } \\
\text { dicontohkan dengan } \\
\text { cara meniru }\end{array}$ \\
\hline $\begin{array}{l}\text { (BB) } \\
\text { (MB) } \\
(\mathrm{BSH}) \\
(\mathrm{BSB})\end{array}$ & \multicolumn{5}{|c|}{$\begin{array}{l}\text { artinya Belum Berkembang: bila anak melakukannya harus dengan bimbingan atau dicontohkan oleh guru; } \\
\text { artinya Mulai Berkembang: bila anak melakukannya masih harus diingatkan atau dibantu oleh guru; } \\
\text { artinya Berkembang Sesuai Harapan: bila anak sudah dapat melakukannya secara mandiri dan konsisten tanpa harus diingatkan } \\
\text { atau dicontohkan oleh guru; } \\
\text { artinya Berkembang Sangat Baik: bila anak sudah dapat melakukannya secara mandiri dan sudah dapat membantu tamannya yang } \\
\text { belum mencapai kemampuan sesuai indikator yang diharapkan. }\end{array}$} \\
\hline
\end{tabular}




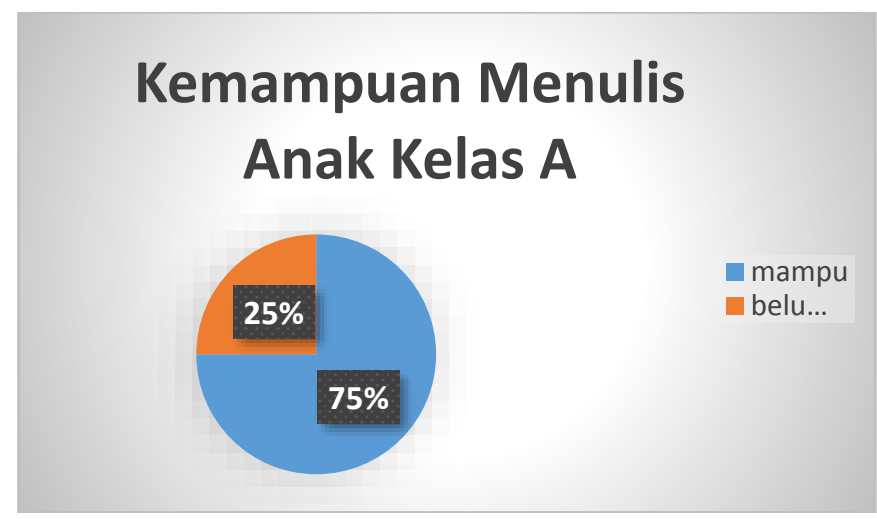

Gambar 1. Diagram kemampuan menulis anak kelas A

\section{Pembahasan}

Hasil penelitian pada pengembangan kemampuan menulis anak usia 4-5 tahun dengan Metode Struktur Analitik Sintetik (SAS) mampu menstimulasi kemampuan menulis anak. 6 subjek penelitian dari 8 murid TK Kreatif Primagama kelas A dengan indikator penelitian sudah sesuai dengan STTPA 137 Tahun 2014 yaitu mengenal simbol-simbol huruf,mencoret tulisan bermakna dan meniru huruf $\mathrm{h}$ $\mathrm{i}-\mathrm{j}$.

Dengan penerapan metode Struktur Analitik Sintetik (SAS), dalam pembelajaran di kelas, anak belajar membaca huruf dan angka bersama-sama dengan pemberian contoh pengucapan oleh guru dan ditirukan murid yang terdapat di area read and mathematic corner, kemudian guru menulis angka-angka di dalam kotak yang dibuat dengan alur cerita, dan anak dapat meneruskan angka yang terdapat di dalam kotak yang kosong sesuai dengan urutannya. Dari kegiatan menulis urutan angka tersebut, terdapat satu anak yang belum mampu mengikuti kegiatan menulis angka di dalam kotak, sehingga perlu bantuan dan diberi garis putus-putus agar anak dapat menebalkan angka. Terdapat satu anak yang mulai berkembang dalam kegiatan ini, sehingga hanya diperlihatkan gambar angka dari media flash card dan anak mampu menulis secara mandiri sesuai yang dilihatnya. Terdapat lima anak yang sudah berkembang sesuai harapan, anak mampu menuliskan huruf sesuai dengan urutannya tanpa bantuan guru. Dan juga terdapat satu anak yang sudah berkembang sangat baik, ketika temannya tidak bisa ia mampu membantu dengan cara ikut menjawab.

Kegiatan kedua yaitu membuat coretan bermakna dengan crayon dalam lembar karya anak atau LKA. Dalam kegiatan ini guru memberikan tugas menulis angka dan membandingkan dengan simbol $=$ dan $\neq$. Anak dapat menulis simbol coretan yang mengartikan jumlah dua gambar yang berbeda. Kegiatan ketiga yaitu menirukan huruf h-i-j. Sebelum anak mengerjakan tugas di LKA, anak menuliskan nama masing-masing terlebih dahulu. Terdapat dua anak yang belum mampu menuliskan nama secara mandiri sehingga diberikan bantuan garis putus-putus dan anak menebalkannya. Terdapat satu anak mulai berkembang dengan tulisan yang masih sulit terbaca, serta empat anak berkembang sesuai harapan, dan satu anak berkembang sangat baik. Hal ini berkaitan dengan motorik halus anak yang masih dalam tahap penyesuai dari yang menggunakan crayon di mana ketebalannya berbeda dengan pensil.

Dari hasil penelitian, guru dalam kegiatannya menggunakan media flashcard yang menarik minat murid karena bentuk dan warna yang mencolok sehingga anak dapat fokus dan berpusat pada media yang dibawa. Selain itu, anak juga dapat memainkan media sendiri dengan mengurutkan sesuai abjad. Dengan adanya media menjadi daya tarik anak untuk memperhatikan guru dalam menyampaikan informasi, bentuk, dan warna yang dapat dimodifikasi sesuai dengan materi dan tahap usia anak sehingga anak juga dapat memainkannya sendiri maupun bermain bersama guru pada saat apersepsi dan penutupan.

Setelah kegiatan berlangsung, keberhasilan perkembangan menulis anak di deskripsikan kedalam daily record atau biasa disebut dengan buku penghubung antara guru dan orang tua dalam mengkomunikasikan tahapan perkembangan anak selama di sekolah. Di dalam daily record atau buku penghubung, guru menyampaikan kepada orang tua untuk mengulang materi pembelajaran yang telah disampaikan di sekolah agar materi yang diajarkan dapat optimal. Sejalan dengan adanya kolaborasi antara lingkungan keluarga dan sekolah mengindikasikan adanya keberhasilan dalam pengembangan 
keterampilan anak berkembang dengan sangat baik. Oleh karena itu, kerjasama yang terbentuk akan dapat mempengaruhi perkembangan anak selanjutnya.

Kendala yang dihadapi guru dalam pengembangan menulis anak usia dini adalah membedakan beberapa huruf yang hampir sama, seperti huruf " $p$ dan $q$ ", " $b$ dan $d$ ", serta " $n$ dan $\underline{u}$ ". Kendala lainnya yaitu tahap perkembangan menulis anak yang berbeda-beda sehingga dalam pembelajaran stimulus yang diberikan gurupun berbeda sesuai dengan tahap perkembangan anak. Tulisan yang masih sulit untuk dibaca karena motorik halus anak dalam memegang pensil belum sempurna dan masih dalam tahapan peralihan penggunaan crayon yang mudah di genggam ke pensil yang lebih ramping.

Adanya kendala di beberapa anak yang belum berkembang, guru memberikan stimulasi yang lebih agar anak dapat setara dengan tahapan perkembangan usianya. Dalam hasil observasi ini, anak yang belum berkembang tidak dapat dikatakan terlambat dalam pengembangan menulis anak, karena usia anak belum sampai 4 tahun. Namun guru tetap memberikan pengayaan ketika pembelajaran anak tersebut diberikan kesempatan lebih banyak untuk membantu mengerjakan tugas didepan, agar kemampuannya dapat berkembang tetapi tidak untuk memaksakan lebih dari tahapan perkembangan anak.

Abdurrahman (2012: 42) dalam (Hajani, 2014), layanan yang dapat diberikan terhadap anak kesulitan menulis permulaan atau menulis dengan tangan adalah:

1) Melakukan assessment terhadap kemampuan menulis: terdiri dari assessment formal dengan basic school skills inventory-diagnostik untuk anak usia empat tahun dan informal dengan observasi serta melakukan analisis pola-pola tulisan anak (bentuk huruf, ukuran, proporsional, dan kesejajaran, kualitas garis, jarak huruf, kemiringan huruf, dan kecepatan menulis).

2) Perbaikan terhadap kesalahan anak dalam menulis dilakukan melalui pelajaran remidi yang sesuai dengan tipe kesalahan.

Pengaruh orangtua yang aktif dalam memantau perkembangan anak disekolah serta cara orang tua untuk mengulang kegiatan maupun materi yang disampaikan guru pada saat pembelajaran. Beberapa keberhasilan anak dalam menulis adalah komunikasi orang tua terhadap anak dan guru kelas, serta pengoptimalan dirumah dalam pembiasaan anak untuk menulis sesuai tahapan usia.adanya hambatan anak untuk sulit menulis adalah tidak adanya pendampingan orang tua dalam belajar anak dirumah.selain itu, usia yang terpaut jauh dari teman-teman disekolah. Meskipun dalam kelas anak dirasa tertinggal namun jika dilihat dari usia anak sudah sesuai dengan perkembangannya, sehingga guru hanya memberikan stimulus atau pancingan agar anak lebih bisa mengikuti teman dikelasnya tanpa ada keharusan melampaui aspek diatas usianya.

\section{SIMPULAN}

Pengembangan kemampuan menulis pada anak usia empat sampai lima tahun kelas A TK Kreatif Primagama dengan Metode pembelajaran Struktur Analitik Statistik (SAS) membangun dialog/cerita dalam proses pembelajaran mampu mengembangkan kemampuan menulis anak secara bertahap, sesuai dengan usia anak. Dengan adanya metode tersebut terdapat beberapa aspek yang dikembangkan. Adanya kegiatan bercerita, anak lebih mampu memahami simbol-simbol yang dikenalkan serta pemahaman simbol sesuai dengan cerita yang diangkat oleh guru.

Media Flashcard sebagai alat dalam menyalurkan pengetahuan kepada anak dengan teknik bermain, sehingga anak dapat dengan senang dan mudah menerima materi. Media flashcard menjadi ketertarikan sendiri untuk anak, tampilan yang menarik, dan dapat dimodifikasi sesuai dengan tahap usia anak serta warna dan bentuk yang dekat dengan anak sehingga anak timbul kesenangan dalam ikut memainkannya.

Kolaborasi Tri Pusat Pendidikan berpengaruh pada psikis anak dalam pengembangan semua aspek perkembangan, termasuk keterampilan menulis. Komunikasi yang aktif antara agen pembentuk anak data menjadi usaha optimal baik pengenalan simbol-simbol sampai pada tahap menuliskan simbol-simbol yang dipahami anak adanya pengulangan dirumah sebagai "review" atas materi yang telah diberikan disekolah.

Hasil observasi kelas dengan subjek penelitian dari delapan murid, enam di antaranya telah berkembang sesuai indikator perkembangan sesuai harapan. Dua dari delapan murid belum mampu berkembang sesuai harapan di antara alasannya karena usia yang lebih muda dari temannya yaitu usia 3,5 Tahun,sehingga memerlukan bantuan dalam menuliskan namanya. 


\section{UCAPAN TERIMA KASIH}

Mengucapkan terima kasih yang sebesar-besarnya kepada TK Kreatif Primagama yang telah membantu kegiatan penelitian kali ini. Terima kasih kami sampaikan kepada:

1. Ibu Dr.Siti Wahyuningsih, S.Pd.,M.Pd, Selaku Kepala Prodi Pendidikan Guru Pendidikan Anak Usia Dini

2. Ibu Ruli Hafidah,S.Pd.,M.Pd, Selaku dosen mata kuliah Pengembangan Bahasa Anak Usia Dini

3. Ibu Vera Sholihah, S.Pd,.M.Pd, Selaku dosen mata kuliah Pengembangan Bahasa Anak Usia Dini

4. Bunda Nurma, sebagai narasumber dan guru kelas TK Kreatif Primagama

5. Bunda-bunda pengajar TK Kreatif Primagama

6. Murid-murid dari TK Primagama, sebagai subyek penelitian ini

\section{DAFTAR PUSTAKA}

Anggalia, A., \& Karmila, M. (2013). Upaya Meningkatkan Kemampuan Bahasa Ekspresif Anak dengan Menggunakan Media Boneka Tangan Muca (Moving Mouth Puppet ) pada Kelompok A Tk Kemala Bhayangkari 01 Semarang. Jurnal Penelitian PAUDIA, 1-27. Retrieved from http://journal.upgris.ac.id/index.php/paudia/article/view/509

Asiah, N. (2018). Pembelajaran Calistung Pendidikan Anak Usia Dini dan Ujian Masuk Calistung Sekolah Dasar di Bandar Lampung. Terampil : Jurnal Pendidikan dan Pembelajaran Dasar, 5(1), 19. https://doi.org/10.24042/terampil.v5i1.2746

Dadan Suryana. (n.d.). Hakikat Anak Usia Dini. JURNAL UT, 1-65. Retrieved from http://repository.ut.ac.id/4697/1/PAUD4107-M1.pdf

Hajani, T. J. (2014). Kemampuan Menulis Anak Usia Dini. jurnal unib, 1-51. Retrieved from http://repository.unib.ac.id/8477/2/I\%2CII\%2CIII\%2CI-14-tri-FK.pdf

Kesowo, B. (2003, July 8). Undang-Undang Republik Indonesia Nomor 20 Tahun 2003 Tentang Sistem Pendidikan Nasional.

NuH, M. (2014). Peraturan Menteri Pendidikan dan Kebudayaan Republik Indonesia Nomor 137 Tahun 2014. Retrieved from https://www.academia.edu/37817634/Permendikbud_no_137_tahun

Prastiwi, Widi. (2012). Penerapan Metode Struktur Analitik Sintetik ( SAS ) untuk Meningkatkan Kemampuan Mengenal Membaca dan Menulis Permulaan untuk Anak Usia Dini di TK N Pembina Cawas Kelompok B Tahun Pelajaran 2011/2012. digilib.uns.ac.id, 1-118. Retrieved from https://digilib.uns.ac.id

Tatik Ariyanti. (2016). Pentingnya Pendidikan Anak Usia Dini bagi Tumbuh Kembang Anak The Importance Of Childhood Education For Child Development. Jurnal UMP, 8, 1-9. 